Document downloaded from:

http://hdl.handle.net/10251/149535

This paper must be cited as:

Mancinelli, G.; Chainho, P.; Cilenti, L.; Falco, S.; Kapiris, K.; Katselis, G.; Ribeiro, F. (2017). The Atlantic blue crab Callinectes sapidus in southern European coastal waters: distribution, impact and prospective invasion management strategies. Marine Pollution Bulletin. 119(1):511. https://doi.org/10.1016/j.marpolbul.2017.02.050

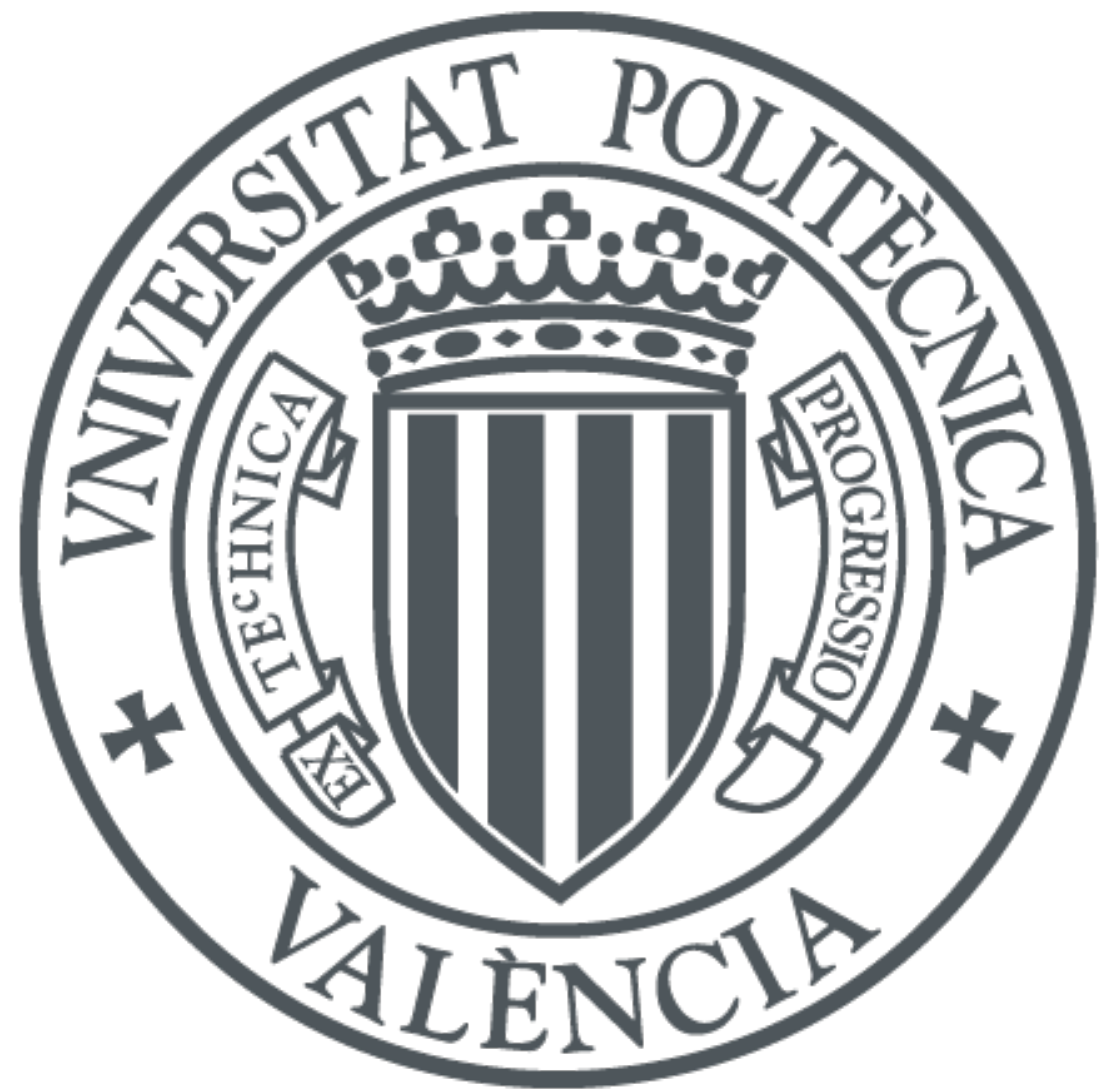

The final publication is available at

https://doi.org/10.1016/j.marpolbul.2017.02.050

Copyright Elsevier

Additional Information 
Review

\title{
The Atlantic blue crab Callinectes sapidus in southern European coastal waters: Distribution, impact and prospective invasion management strategies
}

\author{
Giorgio Mancinelli ${ }^{\mathrm{a}, *}$, Paula Chainho ${ }^{\mathrm{b}}$, Lucrezia Cilenti ${ }^{\mathrm{c}}$, Silvia Falco ${ }^{\mathrm{d}}$, Kostas Kapiris ${ }^{\mathrm{e}}$, George Katselis ${ }^{\mathrm{f}}$, \\ Filipe Ribeiro $^{\mathrm{b}}$ \\ a Department of Biological and Environmental Sciences and Technologies, University of Salento, Lecce, Italy \\ ${ }^{\mathrm{b}}$ MARE - Marine and Environmental Sciences Centre, Faculdade de Ciencias, Universidade de Lisboa, Lisboa, Portugal \\ c Institute of Marine Science (ISMAR), National Research Council (CNR), Lesina, FG, Italy \\ d Institut d'Investigació per a la Gestió Integrada de zones Costaneres (IGIC), Universitat Politècnica de València, Grau de Gandia, Spain \\ e Institute of Marine Biological Resources and Inland Waters, HCMR, Anavissos, Athens, Greece \\ ${ }^{\mathrm{f}}$ Technological Educational Institute of Western Greece, Department of Fisheries and Aquaculture Technology, Messolonghi, Greece
}

\section{A R T I C L E I N F O}

\section{Article history:}

Received 19 November 2016

Received in revised form 8 February

2017

Accepted 15 February 2017

Available online $\mathrm{xxx}$

\section{Keywords}

Callinectes sapidus

Mediterranean and Black Seas

Invasive species

Control management

Marine strategy framework directive

EU regulation 1143/2014

\section{A B S T R A C T}

The native distribution of the blue crab Callinectes sapidus in the western Atlantic extends from Nova Scotia to Argentina. Introduced to Europe at the beginning of the 20th century, it is currently recorded almost ubiquitously in the Mediterranean and in the Black Sea. An overview of the occurrence, abundance, and ecological impact of the species in southern European waters is provided; additionally, we present a pragmatic assessment of its management scenarios, explicitly considering the dual nature of $C$. sapidus as both an invasive species and a fishery resource. We emphasise that the ongoing expansion of $C$. sapidus in the region may represent a stimulating challenge for the identification and implementation of future strategies in the management of invasive crustaceans. The impact of the invader could be converted into an enhancement of the services delivered by southern European coastal ecosystems, while mitigation costs could be transformed into profits for local populations.

(C) 2016 Published by Elsevier Ltd.

\section{Introduction}

In the last few decades, the Mediterranean Sea and southern European waters (SEW hereafter) in general have experienced a dramatic increase in non-indigenous flora and fauna (Coll et al., 2010; Chainho et al., 2015). Crustaceans are emblematic of this ongoing process: in 2008, the CIESM Atlas of Exotic Species listed 70 non-indigenous crustaceans in the Mediterranean Sea, while in subsequent years, 106 and 242 species were respectively listed by Galil (2011) and Nunes et al. (2014). Among other taxa, brachyurans made up a large part of these, with 44 species listed in 2011 (Brockerhoff and McLay, 2011). To date, 58 species have been recorded (Fig. 1).

Interestingly, the Atlantic blue crab Callinectes sapidus Rathbun, 1896 (Brachyura: Portunidae) occurs in seven of the nine South-European Marine Ecoregions (Fig. 1). Native to the western Atlantic Ocean, the blue crab was recorded in Europe for the first time in 1901 on the Atlantic coast of France. In the Mediterranean Sea it was recorded in 1949 (but probably as early as 1935: Enzenroß et al.,

* Corresponding author.

Email address: giorgio.mancinelli@unisalento.it (G. Mancinelli)
1997), and along the Portuguese coasts in 1978 (Castejón and Guerao, 2013; Ribeiro and Veríssimo, 2014). Ballast waters are considered the most probable introduction vector (Nehring, 2011).

In the eastern United States, C. sapidus is known to play a key role in the structure and function of coastal benthic food webs, either as a keystone species or by inducing trophic cascades (Baird and Ulanowicz, 1989; Silliman and Bertness, 2002; Hines, 2007; O'Connor et al., 2008; see also Boudreau and Worm, 2012 for a recent review). In the Mediterranean, the blue crab is currently considered an invasive alien species (IAS hereafter; Zenetos et al., 2005; Katsanevakis et al., 2014). However, the negative effects of the blue crab on invaded benthic communities and on ecosystems functioning and delivery of goods and services are only assumed (but see below for recent counterexamples), and a general lack of ecological information actually occurs. Intriguingly, in the United States the blue crab is considered a valuable seafood and supports an important fishery (Sharov et al., 2003; Perry, 2015). In the last decade, several investigations have emphasised the high nutritional qualities of Mediterranean blue crab meat (among others, Küçükgülmez and Çelik, 2008; Zotti et al., 2016a), and small C. sapidus fisheries are currently located in Turkey (Ayas and Ozogul, 2011) and northern Greece (Kevrekidis et al., 2013). 


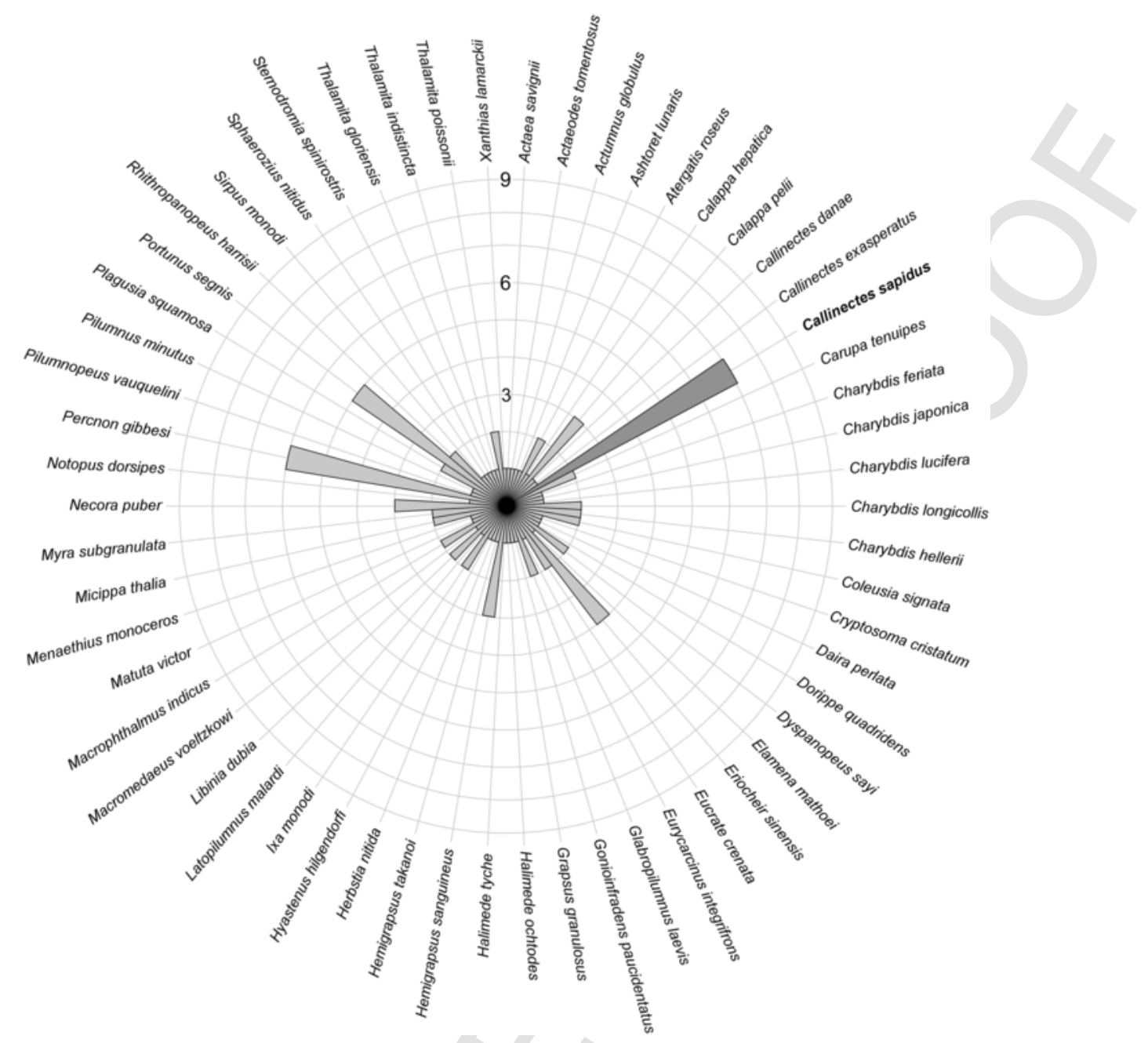

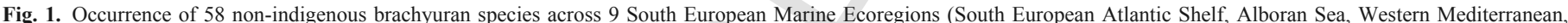

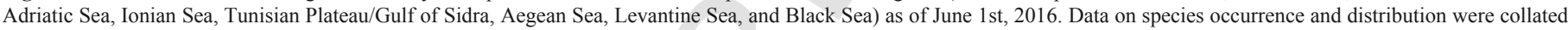

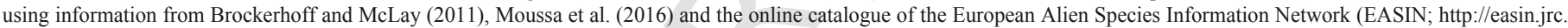

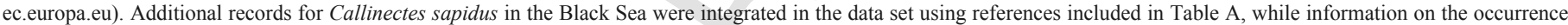
of Portunus segnis in the Tunisian Plateau/Gulf of Sidra region were based on Rabaoui et al. (2015).

In 2011, Nehring argued that "...comprehensive analyses about the economic benefits and disadvantages of $C$. sapidus in its introduced range are not done so far", emphasising the need for an immediate effort to establish the framework for effective control and management policies for this species. The aim of the present overview is to acknowledge this still unanswered challenge and to achieve two specific, interconnected objectives.

The first is to identify the limitations currently limiting a robust assessment of the ecological impact of Callinectes sapidus in invaded SEW. To this end, we provide a state-of-art review of the expansion of the species in the region, from the Mediterranean Sea and Black Sea to the Atlantic coasts of the Iberian Peninsula, complemented by an evaluation of the abundance and other demographic parameters of established populations, and an assessment of the investigations performed to estimate their effects on invaded ecosystems.

The conceptual approach adopted here explicitly follows that of Parker et al. (1999), for which the overall impact of a non-indigenous species depends upon its distribution, abundance and per-capita ecological effect. Given the generally huge spectrum of biotic interactions involving an invader (including competition and predation as well as facilitation and mutualism) per-capita effects are hard to quantify and subject to practical limitations regarding their estimation (Ricciardi et al., 2013). Indeed, using the abundance and distribution of a species alone as surrogate impact estimators, although widely accepted (e.g. EC, 2008a), actually confounds the distinction between the concepts of invasiveness and impact (see Ricciardi et al., 2013 and literature cited therein for definitions).

Thus, we reviewed the most recent attempts to assess the ecological effect of $C$. sapidus on invaded ecosystems. An effort was made to include aspects related to genetics and diseases, widely investigated in native habitats yet to date completely unexplored in SEW.

The second aim of the paper is to provide an appraisal of future blue crab management scenarios, setting out the challenges entailed in a robust, integrated management of the blue crab as both an invasive species and a fishery resource is performed. A concise analysis is presented, that may serve to identify the key issues, gaps in knowledge, and challenges to be addressed on the national and trans-national scale. The ultimate aim is to achieve a virtuous synthesis between the need to control an invasive species and mitigate its ecological impact, and the concrete opportunity to value it as a fishery resource. 


\section{Distribution and abundance}

Fig. 1 already indicates the almost ubiquitous distribution of Callinectes sapidus across south European waters. A more detailed overview of its occurrence was provided by Nehring in 2011. However, in the last few years the number of records in SEW has increased considerably.

Table A (online supplementary information) and Fig. 2 summarise the studies published in the last 20 years, together with recent unpublished records from Greece, Italy and Spain. The literature search was performed using the online databases ISI Web of Science, Scopus, BioAbstracts, PubMed, and JSTOR in May 2016. A multiple search criterion was adopted, using combinations of the keywords "Callinectes sapidus" or "blue crab" and "Mediterranean Sea" or "Black Sea". Additional studies were found by checking the references of collected papers, performing general searches on the world wide web, and contacting authors for additional suggestions. Data on blue crab populations in Portuguese waters were directly provided by two of the authors (P.C. and F. R.). The search produced 54 references were collected; the 43 studies included in Table A and Fig. 1 were selected in a three steps approach using a title/abstract/full text screening procedure (see Mangano and Sarà, 2017 for details).

Three main issues are worth highlighting: i) an expansion of the species towards the western Mediterranean Sea and Portuguese Atlantic waters. Specifically, unpublished data on the occurrence of the species along the Spanish Valencian coast in 2014-2015, combined with the number of captured individuals, indicate that in this area the species is established and is currently expanding its range; ii) the widespread distribution of the blue crab in Greece and, in general, in the Ionian - Adriatic area. In the Aegean and Levantine basins the blue crab is to date almost ubiquitous, being recorded even in freshwaters
(Lake Volvi: Kapiris et al., 2014). The species has also become common in western Greece along the Ionian coasts (Fig. 1; see also notes in Table A). Accordingly, records have increased considerably in the eastern Ionian (see insert in Fig. 1) and throughout the Adriatic Sea, with repeated observations in Italy, Croatia, Montenegro, and Albania; and iii) the species is also expanding in the Black Sea: in addition to a number of relatively old records from the northern area of the basin, there have been several recent observations along the south-eastern coasts.

From Table A it is apparent that most of the records are from coastal habitats close to freshwater inputs. This is not surprising, as blue crabs use all salinity regimes in order to complete their life cycle, and low-salinity environments are used for mating and as nursery habitats (Hines, 2007). Identifying the causes of the current expansion of the species in SEW is beyond the scope of this review. However, climate change may play a role. Warming of coastal waters is argued to have promoted the recruitment of the crab to the Gulf of Maine $100 \mathrm{Km}$ north of its historical range (Johnson, 2015). Hines et al. (2010) analysed latitudinal patterns of reproduction and other life cycle parameters, highlighting the importance of seasonal temperature variations (see also Colton et al., 2014 for a more general appraisal). In environments characterised by winter water temperatures below $10{ }^{\circ} \mathrm{C}$, blue crabs become inactive, with negative effects on both survival and reproduction rates. The current increase in the surface temperature of south Atlantic and Mediterranean waters, with even more evident warming effects in the Adriatic/Ionian area and in the Black Sea (Ulbrich et al., 2013), is reducing the severity of winters. This may have positively affected the survival rate of overwintering populations (see Bauer and Miller, 2010a, 2010b for examples in the United States) as well as their maturation rates and brood production, ultimately increasing their fitness and promoting their expansion.

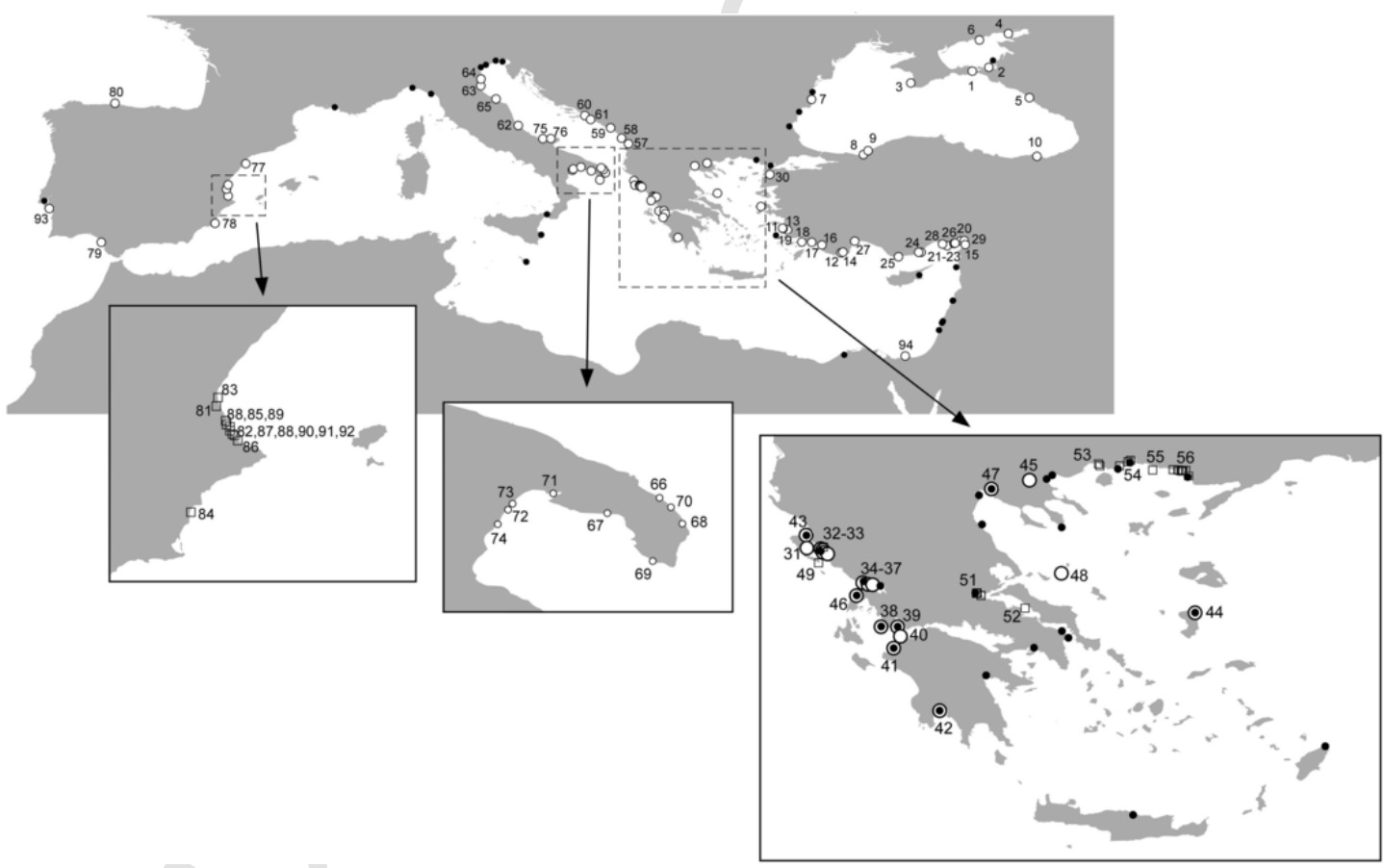

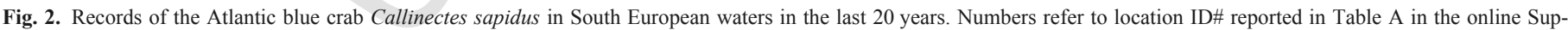

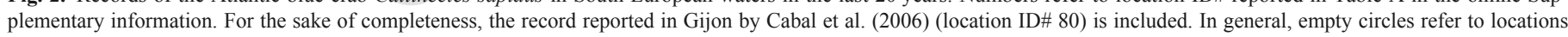

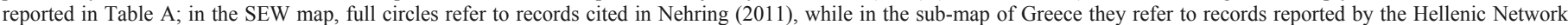

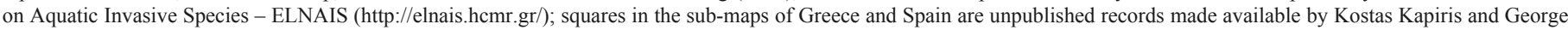
Katselis (Greece) and Silvia Falco (Spain). 
In order to corroborate this hypothesis, more demographic data are needed for blue crab populations in SEW. Table A shows that most information consists of sporadic records of single individuals. With the noticeable exception of Turkey (Atar and Seçer, 2003; Türeli et al., 2016), there is a relatively low number of studies providing quantitative data on the abundance and other demographic parameters of established populations, e.g. monthly or at least seasonally-resolved catch data, the capture of juveniles and ovigerous females, length-weight relationships, etc. (but see Carrozzo et al., 2014 and Mancinelli et al., 2013a for Italy), thus limiting any comparison within SEW and, more importantly, between SEW and Atlantic populations. Additionally, while the connectivity of blue crab populations in native Atlantic habitats has been widely investigated by molecular approaches (Yednock and Neigel, 2014; Lacerda et al., 2016), no studies are to date available for $C$. sapidus populations in SEW. These knowledge gaps hinder any assessment of the actual ecological impact of the blue crab (see next section), and represent one of the first issues that must be dealt with in future control and mitigation actions. In addition, they hamper a comprehensive evaluation of the role of niche conservation mechanisms and niche variation phenomena (Wiens et al., 2010; Guisan et al., 2014) in the ongoing expansion of the species. Lastly, it makes it harder to predict the impact of climate change, as recently investigated in other invasive marine brachyurans (e.g. Carcinus maenas: Compton et al., 2010).

\section{Ecological impact}

Callinectes sapidus has long been considered an IAS (Zenetos et al., 2005), with negative impacts on human activities. However, reports of negative effects on fishing, by e.g. mutilating fish caught in traps and tearing nets (Nehring, 2011 and literature cited therein; Perdikaris et al., 2016), have mainly been anecdotal. A quantitative assessment of the impact on Ionian and Aegean fisheries in Greece was recently conducted (July-October 2015) by means of questionnaires, the results indicating that where blue crab populations have reached high abundances in the last decade (i.e., Vistonida lagoon in the North Aegean Sea), considerable negative effects on fishing activities have been perceived by local populations (Katselis, unpublished data).

Besides a presumed high degree of competition with native brachyurans (Gennaio et al., 2006; Mancinelli et al., 2013a), and a post facto confirmation of its high invasive potential in Greek waters by means of the Marine Invertebrate Invasiveness Scoring Kit (MI-ISK by CEFAS: https://www.cefas.co.uk/services/ research-advice-and-consultancy/invasive-and-non-native-species/; Perdikaris et al., 2016), little information is available on the functional role of the species in Europe. Invertebrate and vertebrate predators of C. sapidus in SEW are to date unidentified, as well as its parasites and pathogens (see Nagle et al., 2009 for native habitats; but see Mancinelli et al., 2013b for an unconfirmed claim of parasitic dynoflagellates of the genus Hematodinium in SE Italy) In addition, the trophic ecology of the species is virtually unexplored, the only exception being recent stable isotopes investigations (Mancinelli et al., 2013a; Carrozzo et al., 2014; Mancinelli et al., 2016a, 2017). A high size- and site-related variability in trophic position has been shown, implying that the blue crab has the potential to impact benthic communities at multiple trophic levels. These studies indicate that analysis of carbon and nitrogen stable isotopes (SIA hereafter) may represent a valuable approach to understand the overall ecological impact of the species. Bodey et al. (2011) reviewed the advantages and limitations of this method for assessing the impact of IASs, while Mancinelli and Vizzini (2015) further emphasised the possibility of using recent community-scale isotopic metrics to provide a quantitative assess- ment of the overall impact of a species on an invaded community. Some recent investigations of marine food webs provide support for this approach (Fanelli et al., 2015; Fry and Davis, 2015) and indicate that SIA-based, community-scale studies may overcome most of the limitations affecting the estimation of per-capita ecological effects. Furthermore, SIA may also provide sound methodological support for the analysis of pollutant transfer routes in invaded food webs (e.g. Thomas et al., 2016 for a freshwater example). Atlantic blue crab populations have long been used as pollution indicators (e.g. heavy metals: Weinstein et al., 1992; Adams and Engel, 2014). In SEW, a considerable quantity of information is available for the Levantine sector (Türkmen et al., 2008; Mutlu et al., 2011). However, outside this area only Zotti et al. (2016b) have provided data on heavy metal concentrations in blue crabs from SE Italy.

\section{To manage or not to manage?}

It is apparent that more than sixty years after its official introduction, the blue crab has established itself in the Mediterranean Sea and neighbouring waters; most importantly, it is currently expanding its range towards the western sectors of the basin, the Adriatic Sea and the Black Sea. Given these premises, three alternative future scenarios are possible.

The first is simply a "no action" scenario. Overfishing, pollution, human-induced changes in oceanographic conditions or natural buffering due to intra- or inter-specific density-dependent controls within benthic communities may ultimately limit or even reverse the crab's expansion. Such an approach clearly runs counter to the efforts currently being made by the European Union to implement regulatory guidelines concerning the control of IASs such as the Strategy on Invasive Species (EC, 2008b), the Marine Strategy Framework Directive (MSFD; EC, 2008a), the Biodiversity Strategy (EC, 2011) and the Regulation on the Prevention and Management of the Introduction and Spread of Invasive Alien Species (EU, 2014).

The second option is to develop a policy of species control. In principle, eradication remains the primary approach. However, the requirements in terms of time and monetary resources for completing successful eradication campaigns, particularly for aquatic invaders, are acknowledged to be huge (Lampert et al., 2014). Similarly, post-establishment control measures, whether they are aimed at reducing the presence of the invader or limiting its further spread, both require considerable investment in terms of time and money (Simberloff et al., 2013). In addition, when little or no knowledge is available on the connectivity of invasive populations (see previous paragraph), eradication attempts become increasingly difficult and often result in a strategy of long-term commitment to local control (Hulme, 2006).

In our opinion, the current distribution of the blue crab in SEW is so vast that eradication would be not only costly, but actually unfeasible. We thus identify a third approach, involving advanced management of the species as a high-value fishery resource to be implemented as a mitigation strategy.

The proposed approach requires an estimation of the services and disservices (sensu Mulder et al., 2015) provided by the species to coastal areas, and the implementation of a management scenario aimed at minimising the control and mitigation costs of the blue crab as an invasive species by exploiting it as a shellfish product.

The state-of-the-art knowledge on the blue crab in SEW includes information on its distribution and data on its nutraceutical value (e.g. Türeli et al., 2000; Küçükgülmez and Çelik, 2008) and contamination by heavy metals and other pollutants (e.g. Ayas and Ozogul, 2011; Genc and Yilmaz, 2015), primarily in Levantine populations. Additional, preliminary assessments of the functional role of the species within invaded food webs are limited to Italian and Croatian popula- 
tions. Coupled with the huge body of information on blue crab populations in native habitats regarding their ecological role, pathogens, and connectivity, they could provide a robust basis for the future development of ecological and demographic investigations standardised across southern European countries. The results need to be integrated with data on the crab's effects on fishing activities collected by means of questionnaires given to fishermen and other stakeholders and specifically tailored to local fishing strategies and traditions (Sharp et al., 2011).These efforts will help to fill in the knowledge gaps regarding the ecological and economic disservices caused by the blue crab. In addition, they will provide an opportunity to implement and intercalibrate control procedures and impact assessment protocols - useful for the blue crab as well as for other marine invaders - that are consistent with the legislative and regulatory framework provided by the MSFD and other EU directives on invasive species (e.g. EU, 2014). Most importantly, besides facilitating an assessment of the blue crab's ecological impact by classical approaches (Parker et al., 1999) and helping to target crucial life stages for control management (Nuñez et al., 2012), quantitative demographic information will allow a large-scale assessment of blue crab stocks in SEW. As more crustacean species of increasing socio-economic importance are harvested worldwide (Anderson et al., 2011), Europe is witnessing increased market interest in decapod and brachyuran species (Molfese et al., 2014; see also ICES, 2015). The blue crab is already a valuable shellfish resource in Aegean and Levantine waters, and the development of a fishing sector focusing on the exploitation of the numerically most abundant (and potentially most ecologically impacting) populations may represent an effective mitigation strategy, supporting at the same time the diversification of European shellfish product markets and providing the food industry with a valuable product. A huge body of literature on stock assessment approaches is available for Atlantic populations, together with information on the effectiveness of different fishing methods and approaches (e.g. crab pots, dredging nets, etc.). Although some methods are inappropriate for Europe (e.g. aquaculture), there is a robust knowledge base that can be used for designing effective stock assessments. The limited efforts made to date to verify the occurrence of pollutants and pathogens, require the implementation of standardised procedures for quality control and traceability of the product. Multi-elemental fingerprinting, to date limited to mussels and other bivalves (Ricardo et al., 2015; but see Zotti et al., 2016b), complemented by other "foodomic" techniques (e.g. metabolomic profiling: Zotti et al., 2016a and literature cited therein) may provide effective, standardised procedures for shellfish quality profiling and traceability.

The risk in this scenario is that the blue crab may no longer be seen as an invasive species, achieving a sort of unofficial legitimisation of the risk it represents. In addition, the development of an economically important blue crab fishery may prompt illegal efforts to set up profitable businesses, ultimately promoting invasion (Nuñez et al., 2012). The negative effects of $C$. sapidus on invaded habitats must be made explicit; obviously, the nature and extent of these negative effects must be demonstrated and publicised, and not merely assumed. Thus, a thorough quantitative assessment of the ecological impact of the blue crab is an obligatory step in its management as a fishery resource.

\section{Conclusions}

This review shows that despite the growing number of records testifying to its ongoing expansion, there are still considerable gaps in our knowledge of the demographic and ecological features of Callinectes sapidus in invaded south European waters. It suggests, how- ever, that the blue crab has the potential to be turned into a valuable resource, once its impact on ecosystem services and disservices have been thoroughly assessed. It is worth noting, with regard to the general implications of topics related to Callinectes sapidus, that the Mediterranean Sea is currently invaded by a number of portunid species, including the blue swimming crab Portunus segnis (Rabaoui et al., 2015), a species actively consumed in its native habitats (Giraldes et al., 2016) and locally important in Levantine fish markets (Özcan, 2012). The ongoing invasion by the blue crab and other portunids provides an opportunity to combine the development of successful mitigation and control policies with the exploitation and marketing of shellfish products whose economic value is already acknowledged outside Europe. Thus, management and control costs in invaded habitats may ultimately yield profits for local populations, while the effects of the invader may be greatly reduced, even enhancing the ecosystem goods and services provided by coastal habitats.

\section{Acknowledgments}

Funding from FUR 2013-2014 and 2014-2015 to G. M. is acknowledged. The European Fisheries Fund (FEP) Puglia Region (Italy) supported L. C. (CIP 04/OPI/010) as the scientific head of the MOLEVAR project (Pilot Project for the production of soft crabs from Carcinus aestuarii in Varano lagoon). The Portuguese Science Foundation (FCT) supported F. R. (SFRH/BPD/46761/2008) with a post-doctoral research grant from the Programa Operacional Potencial Humano/Fundo Social Europeu (POPH/FSE). F. R. and P. C. were also supported by the strategic MARE plan - Marine and Environmental Sciences Centre (UID/MAR/04292/2013). Comments from an anonymous reviewer greatly improved an early version of the manuscript. This paper is dedicated to Sofia Mancinelli, thy eternal summer shall not fade.

\section{Appendix A. Supplementary data}

Supplementary data to this article can be found online at http://dx. doi.org/10.1016/j.marpolbul.2017.02.050.

\section{References}

Adams, D.H., Engel, M.E., 2014. Mercury, lead, and cadmium in blue crabs, Callinectes sapidus, from the Atlantic coast of Florida, USA: a multipredator approach Ecotoxicol. Environ. Saf. 102, 196-201.

Anderson, S.C., Flemming, J.M., Watson, R., Lotze, H.K., 2011. Rapid global expansion of invertebrate fisheries: trends, drivers, and ecosystem effects. PLoS One 6 , e14735.

Atar, H.H., Seçer, S., 2003. Width/length-weight relationships of the blue crab (Callinectes sapidus Rathbun 1896) population living in Beymelek lagoon lake. Turk. J. Vet. Anim. Sci. 27, 443-447.

Ayas, D., Ozogul, Y., 2011. The effects of sex and seasonality on the metal levels of different muscle tissues of mature Atlantic blue crabs (Callinectes sapidus) in Mersin Bay, north-eastern Mediterranean. Int. J. Food Sci. Tech. 46, 2030-2034.

Baird, D., Ulanowicz, R.E., 1989. The seasonal dynamics of the Chesapeake Bay ecosystem. Ecol. Monogr. 59, 329-364.

Bauer, L.J., Miller, T.J., 2010. Spatial and interannual variability in winter mortality of the blue crab (Callinectes sapidus) in the Chesapeake Bay. Estuar. Coasts 33, $678-687$.

Bauer, L.J., Miller, T.J., 2010. Temperature-, salinity-, and size-dependent winter mortality of juvenile blue crabs (Callinectes sapidus). Estuar. Coasts 33, 668-677.

Bodey, T.W., Bearhop, S., McDonald, R.A., 2011. Invasions and stable isotope analysis - informing ecology and management. In: Veitch, C.R., Clout, M.N., Towns, D.R. (Eds.), Island Invasives: Eradication and Management. IUCN, Gland, Switzerland, pp. 148-151.

Boudreau, S.A., Worm, B., 2012. Ecological role of large benthic decapods in marine ecosystems: a review. Mar. Ecol. Prog. Ser. 469, 195-213. 
Brockerhoff, A., McLay, C., 2011. Human-mediated spread of alien crabs. In: Galil, B.S., Clark, P.F., Carlton, J.T. (Eds.), In the Wrong Place - Alien Marine Crustaceans: Distribution, Biology and Impacts. Springer-Verlag, Berlin-Heidelberg, pp. 27-106.

Cabal, J., Millán, J.A.P., Arronte, J.C., 2006. A new record of Callinectes sapidus Rathbun, 1896 (Crustacea: Decapoda: Brachyura) from the Cantabrian Sea, Bay of Biscay, Spain. Aquat. Invasions 1, 186-187.

Carrozzo, L., Potenza, L., Carlino, P., Costantini, M.L., Rossi, L., Mancinelli, G., 2014. Seasonal abundance and trophic position of the Atlantic blue crab Callinectes sapidus Rathbun 1896 in a Mediterranean coastal habitat. Rend. Lincei Sci. Fis. Nat. 25, 201-208.

Castejón, D., Guerao, G., 2013. A new record of the American blue crab, Callinectes sapidus Rathbun, 1896 (Decapoda: Brachyura: Portunidae), from the Mediterranean coast of the Iberian Peninsula. Bioinvasions Rec. 2, 141-143.

Chainho, P., Fernandes, A., Amorim, A., Ávila, S.P., Canning-Clode, J., Castro, J.J., Costa, A.C., Costa, J.L., Cruz, T., Gollasch, S., Grazziotin-Soares, C., Melo, R. Micael, J., Parente, M.I., Semedo, J., Silva, T., Sobral, D., Sousa, M., Torres, P., Veloso, V., Costa, M.J., 2015. Non-indigenous species in Portuguese coastal areas, coastal lagoons, estuaries and islands. Estuar. Coast. Shelf Sci. 167, 199-211.

Coll, M., Piroddi, C., Steenbeek, J., Kaschner, K., Lasram, F.B.R., Aguzzi, J., Ballesteros, E., Bianchi, C.N., Corbera, J., Dailianis, T., 2010. The biodiversity of the Mediterranean Sea: estimates, patterns, and threats. PLoS One 5, e11842.

Colton, A.R., Wilberg, M.J., Coles, V.J., Miller, T.J., 2014. An evaluation of the synchronization in the dynamics of blue crab (Callinectes sapidus) populations in the western Atlantic. Fish. Oceanogr. 23, 132-146.

Compton, T.J., Leathwick, J.R., Inglis, G.J., 2010. Thermogeography predicts the potential global range of the invasive European green crab (Carcinus maenas). Divers. Distrib. 16, 243-255.

EC, 2008. Directive 2008/56/EC of the European Parliament and of the Council of 17 June 2008, establishing a framework for community action in the field of marine environmental policy (marine strategy framework directive). Off. J. Eur. Union L164, 19-40.

EC, 2008. Towards an EU strategy on invasive species. In: European Commission. COM/2008/789, European Commission, Brussels.

EC, 2011. Our life insurance, our natural capital: an EU biodiversity strategy to 2020 . In: COM/2011/244. European Commission, Brussels.

Enzenroß, R., Enzenroß, L., Bingel, F., 1997. Occurrence of blue crab, Callinectes sapidus (Rathbun, 1896) (Crustacea, Brachyura) on the Turkish Mediterranean an the adjacent Aegean coast and its size distribution in the bay of Iskenderun. Turk. J. Zool. 21, 113-122.

EU, 2014. Regulation on the prevention and management of the introduction and spread of invasive alien species. In: PE-CONS 70/14. Brussels, European Parliament and Council.

Fanelli, E., Azzurro, E., Bariche, M., Cartes, J.E., Maynou, F., 2015. Depicting the novel Eastern Mediterranean food web: a stable isotopes study following Lessepsian fish invasion. Biol. Invasions 17, 2163-2178.

Fry, B., Davis, J., 2015. Rescaling stable isotope data for standardized evaluations of food webs and species niches. Mar. Ecol. Prog. Ser. 528, 7-17.

Galil, B.S., 2011. The alien crustaceans in the Mediterranean Sea: a historical review. In: Galil, B.S., Clark, P.F., Carlton, J.T. (Eds.), In the Wrong Place - Alien Marine Crustaceans: Distribution. Biology and Impacts. Springer-Verlag, Berlin-Heidelberg, pp. $377-401$.

Genc, T.O., Yilmaz, F., 2015. Bioaccumulation indexes of metals in blue crab inhabiting specially protected area Koycegiz Lagoon (Turkey). Indian J. Anim. Sci. 85, 94-99.

Gennaio, R., Scordella, G., Pastore, M., 2006. Occurrence of blue crab Callinectes sapidus (Rathbun, 1986, Crustacea, Brachyura), in the Ugento ponds area (Lecce, Italy). Thalassia Salentina 29, 29-39.

Giraldes, B.W., Al-Maslamani, I., Al-Ashwel, A., Chatting, M., Smyth, D., 2016. Basic assessment of Portunus segnis (Forskål, 1775) - a baseline for stock management in the Western Arabian Gulf. Egypt. J. Aquat. Res. 42, 111-119.

Guisan, A., Petitpierre, B., Broennimann, O., Daehler, C., Kueffer, C., 2014. Unifying niche shift studies: insights from biological invasions. Trends Ecol. Evol. 29, 260-269.

Hines, A.H., 2007. Ecology of juvenile and adult blue crabs. In: Kennedy, V.S. Cronin, L.E. (Eds.), The Blue Crab: Callinectes sapidus. Maryland Sea Grant College, College Park, Maryland, pp. 565-654.

Hines, A.H., Johnson, E.G., Darnell, M.Z., Rittschof, D., Miller, T.J., Bauer, L.J., Rodgers, P., Aguilar, R., 2010. Predicting effects of climate change on blue crabs in Chesapeake Bay. In: Kruse, G.H., Eckert, G.L., Foy, R.J., Lipcius, R.N., Sainte-Marie, B., Stram, D.L., Woodby, D. (Eds.), Biology and Management of Exploited Crab Populations under Climate Change. Alaska Sea Grant, University of Alaska, Fairbanks, pp. 109-127.

Hulme, P.E., 2006. Beyond control: wider implications for the management of biological invasions. J. Appl. Ecol. 43, 835-847.
ICES, 2015. Interim Report of the Working Group on the Biology and Life History of Crabs (WGCRAB), 3-5 November 2015, Brest, France. ICES CM 2015/SSGEPD:11. 43.

Johnson, D.S., 2015. The savory swimmer swims north: a northern range extension of the blue crab Callinectes sapidus?. J. Crustac. Biol. 35, 105-110.

Kapiris, K., Apostolidis, C., Baldacconi, R., Başusta, N., Bilecenoglu, M., Bitar, G., Bobori, D.C., Boyaci, , Dimitriadis, C., Djurović, M., Dulčić, J., Durucan, F., Gerovasileiou, V., Gökoğlu, M., Koutsoubas, D., Lefkaditou, E., Lipej, L., Marković, O., Mavrič, B., Özvarol, Y., Pesic, V., Petriki, O., Siapatis, A., Sini, M., Tibullo, D., Tiralongo, F., 2014. New Mediterranean marine biodiversity records (April, 2014). Mediterr. Mar. Sci. 15, 198-212.

Katsanevakis, S., Wallentinus, I., Zenetos, A., Leppäkoski, E., Çinar, M.E., Oztürk, B., Grabowski, M., Golani, D., Cardoso, A.C., 2014. Impacts of invasive alien marine species on ecosystem services and biodiversity: a pan-European review. Aquat. Invasions 9, 391-423.

Kevrekidis, K., Antoniadou, C., Avramoglou, K., Efstathiadis, J., Chintiroglou, C., 2013. Population Structure of the Blue Crab Callinectes sapidus in Thermaikos Gulf (Methoni Bay), 15th Pan-Hellenic Congress of Ichthyologists, 10-13 October 2013. Thessaloniki, Greece, 113-116.

Küçükgülmez, A., Çelik, M., 2008. Amino acid composition of blue crab (Callinectes sapidus) from the North Eastern Mediterranean Sea. J. Appl. Biol. Sci. 2, 39-42.

Lacerda, A.L.F., Kersanach, R., Cortinhas, M.C.S., Prata, P.F.S., Dumont, L.F.C., Proietti, M.C., Maggioni, R., D'Incao, F., 2016. High connectivity among blue crab (Callinectes sapidus) populations in the Western South Atlantic. PLoS One 11, e0153124

Lampert, A., Hastings, A., Grosholz, E.D., Jardine, S.L., Sanchirico, J.N., 2014. Optimal approaches for balancing invasive species eradication and endangered species management. Science 344, 1028-1031.

Mancinelli, G., Alujević, K., Guerra, M.T., Raho, D., Zotti, M., Vizzini, S., 2017. Spatial and seasonal trophic flexibility of the Atlantic blue crab Callinectes sapidus in invaded coastal systems of the Apulia region (SE Italy): a stable isotope analysis. Estuar. Coast. Shelf Sci. (in press).

Mancinelli, G., Carrozzo, L., Marini, G., Costantini, M.L., Rossi, L., Pinna, M., 2013. Occurrence of the Atlantic blue crab Callinectes sapidus (Decapoda, Brachyura, Portunidae) in two Mediterranean coastal habitats: temporary visitor or permanent resident?. Estuar. Coast. Shelf Sci. 135, 46-56.

Mancinelli, G., Carrozzo, L., Marini, G., Pagliara, P., Pinna, M., 2013. The co-occurrence of Callinectes sapidus Rathbun, 1896 (Brachyura: Portunidae) and the parasitic dinoflagellate Hematodinium sp. (Dinoflagellata: Syndinidae) in two transitional water ecosystems of the Apulia coastline (South-Italy). Transit. Water Bull. 7, 32-42.

Mancinelli, G., Glamuzina, B., Petrić, M., Carrozzo, L., Glamuzina, L., Zotti, M., Raho, D., Vizzini, S., 2016. The trophic position of the Atlantic blue crab Callinectes sapidus Rathbun 1896 in the food web of Parila Lagoon (South Eastern Adriatic, Croatia): a first assessment using stable isotopes. Mediterr. Mar. Sci. 17, 634-643.

Mancinelli, G., Vizzini, S., 2015. Assessing anthropogenic pressures on coastal marine ecosystems using stable CNS isotopes: state of the art, knowledge gaps, and community-scale perspectives. Estuar. Coast. Shelf Sci. 156, 195-204.

Mangano, M.C., Sarà, G., 2017. Collating science-based evidence to inform public opinion on the environmental effects of marine drilling platforms in the Mediterranean Sea. J. Environ. Manage. 188, 195-202.

Molfese, C., Beare, D., Hall-Spencer, J.M., 2014. Overfishing and the replacement of demersal finfish by shellfish: an example from the English Channel. PLoS One 9, e101506.

Moussa, R., Kapiris, K., Zenetos, A., 2016. Brachyuran diversity along Mediterranean Egypt, with the addition of a new introduced species. Cah. Biol. Mar. 57, 43-49.

Mulder, C., Bennett, E., Bohan, D.A., Bonkowski, M., Carpenter, S.R., Chalmers, R., Cramer, W., Durance, I., Eisenhauer, N., Fontaine, C., Haughton, A.J., Hettelingh, J.P., Hines, J., Ibanez, S., Jeppesen, E., Krumins, J.A., Ma, A., Mancinelli, G., Massol, F., McLaughlin, O., Naeem, S., Pascual, U., Penuelas, J., Pettorelli, N., Pocock, M.J.O., Raffaelli, D., Rasmussen, J.J., Rusch, G., Scherber, C., Setala, H., Sutherland, W.J., Vacher, C., Voigt, W., Vonk, J.A., Wood, S.A., Woodward, G., 2015. 10 years later: revisiting priorities for science and society a decade after the millennium ecosystem assessment. Adv. Ecol. Res. 53, 1-53.

Mutlu, C., Turkmen, M., Turkmen, A., Tepe, Y., 2011. Comparison of metal concentrations in tissues of blue crab, Callinectes sapidus from Mediterranean lagoons. Bull. Environ. Contam. Toxicol. 87, 282-286.

Nagle, L., Place, A.R., Schott, E.J., Jagus, R., Messick, G., Pitula, J.S., 2009 Real-time PCR-based assay for quantitative detection of Hematodinium sp. in the blue crab Callinectes sapidus. Dis. Aquat. Org. 84, 79.

Nehring, S., 2011. Invasion History and Success of the American Blue Crab Callinectes sapidus in European and Adjacent Waters. In: Galil, B.S., Clark, P.F., Carlton, J.T. (Eds.), In the Wrong Place - Alien Marine Crustaceans: Distribution. Biology and Impacts, Springer Netherlands, pp. 607-624. 
Nunes, A.L., Katsanevakis, S., Zenetos, A., Cardoso, A.C., 2014. Gateways to alien invasions in the European seas. Aquat. Invasions 9, 133-144.

Nuñez, M.A., Kuebbing, S., Dimarco, R.D., Simberloff, D., 2012. Invasive species: to eat or not to eat, that is the question. Conserv. Lett. 5, 334-341.

O'Connor, N.E., Grabowski, J.H., Ladwig, L.M., Bruno, J.F., 2008. Simulated predator extinctions: predator identity affects survival and recruitment of oysters. Ecology $89,428-438$.

Özcan, T., 2012. The swimming crab Portunus segnis (Forskål, 1775): host for the barnacle Chelonibia platula (Ranzani, 1818) from the Turkish coast. J. Black Sea/ Mediterr. Environ. 18, 271-278.

Parker, I.M., Simberloff, D., Lonsdale, W.M., Goodell, K., Wonham, M., Kareiva, P.M., Williamson, M.H., Von Holle, B., Moyle, P.B., Byers, J.E., Goldwasser, L., 1999. Impact: toward a framework for understanding the ecological effects of invaders. Biol. Invasions 1, 3-19.

Perdikaris, C., Konstantinidis, E., Gouva, E., Klaoudatos, D., Nathanailides, C., Paschos, I., 2016. Occurrence of the invasive crab species Callinectes sapidus Rathbun, 1896 in NW Greece. Walailak J. Sci. Tech. 13, 1-12.

Perry, H.M., 2015. The blue crab fishery in Mississippi. Gulf Caribbean Res. 5, 39-57.

Rabaoui, L., Arculeo, M., Mansour, L., Tlig-Zouari, S., 2015. Occurrence of the lessepsian species Portunus segnis (Crustacea: Decapoda) in the Gulf of Gabes (Tunisia): first record and new information on its biology and ecology. Cah. Biol. Mar. 56, 169-175.

Ribeiro, F., Veríssimo, A., 2014. A new record of Callinectes sapidus in a western European estuary (Portuguese coast). Mar. Biodivers. Rec. 7, e36.

Ricardo, F., Génio, L., Leal, M.C., Albuquerque, R., Queiroga, H., Rosa, R., Calado, R., 2015. Trace element fingerprinting of cockle (Cerastoderma edule) shells can reveal harvesting location in adjacent areas. Sci. Rep. 5, 1-9.

Ricciardi, A., Hoopes, M.F., Marchetti, M.P., Lockwood, J.L., 2013. Progress toward understanding the ecological impacts of nonnative species. Ecol. Monogr. 83, 263-282.

Sharov, A.F., Vølstad, J.H., Davis, G.R., Davis, B.K., Lipcius, R.N., Montane, M.M., 2003. Abundance and exploitation rate of the blue crab (Callinectes sapidus) in Chesapeake Bay. Bull. Mar. Sci. 72, 543-565.

Sharp, R.L., Larson, L.R., Green, G.T., 2011. Factors influencing public preferences for invasive alien species management. Biol. Conserv. 144, 2097-2104.

Silliman, B.R., Bertness, M.D., 2002. A trophic cascade regulates salt marsh primary production. Proc. Natl. Acad. Sci. U. S. A. 99, 10500-10505.

Simberloff, D., Martin, J.L., Genovesi, P., Maris, V., Wardle, D.A., Aronson, J., Courchamp, F., Galil, B., García-Berthou, E., Pascal, M., Pyšek, P., Sousa, R., Tabacchi, E., Vilà, M., 2013. Impacts of biological invasions: what's what and the way forward. Trends Ecol. Evol. 28, 58-66.

Thomas, S.M., Kiljunen, M., Malinen, T., Eloranta, A.P., Amundsen, P.A., Lodenius, M., Kahilainen, K.K., 2016. Food-web structure and mercury dynamics in a large subarctic lake following multiple species introductions. Freshw. Biol. 61, 500-517.
Türeli, C., Çelik, M., Erdem, , 2000. Comparison of meat composition and yield of blue crab (Callinectes sapidus RATHBUN, 1896) and sand crab (Portunus pelagicus LINNE, 1758) caught in Iskenderun Bay, North-East Mediterranean. Turk. J. Vet. Anim. Sci. 24, 195-204.

Türeli, C., Miller, T.J., Gündogdu, S., Yesilyurt, I.N., 2016. Growth and mortality of blue crab (Callinectes sapidus) in the north-eastern Mediterranean Sea. J. FisheriesSciences.com 10, 55-62.

Türkmen, M., Türkmen, A., Tepe, Y., Ateş, A., Gökkuş, K., 2008. Determination of metal contaminations in sea foods from Marmara, Aegean and Mediterranean seas: twelve fish species. Food Chem. 108, 794-800.

Ulbrich, U., Xoplaki, E., Dobricic, S., García-Herrera, R., Lionello, P., Adani, M., Baldi, M., Barriopedro, D., Coccimiglio, P., Dalu, G., Efthymiadis, D., Gaetani, M., Galati, M.B., Gimeno, L., Goodess, C.M., Jones, P.D., Kuglitsch, F.G., Leckebusch, G.C., Luterbacher, J., Marcos-Moreno, M., Mariotti, A., Nieto, R., Nissen, K.M., Pettenuzzo, D., Pinardi, N., Pino, C., Shaw, A.G.P., Sousa, P., Toreti, A., Trigo, R.M., Tsimplis, M., 2013. Past and current climate changes in the Mediterranean region. In: Navarra, A., Tubiana, L. (Eds.), Regional Assessment of Climate Change in the Mediterranean. Air, Sea and Precipitation and Water, Vol. 1. Springer Netherlands, Dordrecht, pp. 9-51.

Weinstein, J.E., West, T.L., Bray, J.T., 1992. Shell disease and metal content of blue crabs, Callinectes sapidus, from the Albemarle-Pamlico Estuarine System, North Carolina. Arch. Environ. Contam. Toxicol. 23, 355-362.

Wiens, J.J., Ackerly, D.D., Allen, A.P., Anacker, B.L., Buckley, L.B., Cornell, H.V., Damschen, E.I., Jonathan Davies, T., Grytnes, J.-A., Harrison, S.P., Hawkins, B.A., Holt, R.D., McCain, C.M., Stephens, P.R., 2010. Niche conservatism as an emerging principle in ecology and conservation biology. Ecol. Lett. 13, 1310-1324.

Yednock, B.K., Neigel, J.E., 2014. Detecting selection in the blue crab, Callinectes sapidus, using DNA sequence data from multiple nuclear protein-coding genes PLoS One 9, e99081.

Zenetos, A., Çinar, M.E., Pancucci-Papadopoulou, M.A., Harmelin, J.G., Furnari, G., Andaloro, F., Bellou, N., Streftaris, N., Zibrowius, H., 2005. Annotated list of marine alien species in the Mediterranean with records of the worst invasive species. Mediterr. Mar. Sci. 6, 63-118.

Zotti, M., De Pascali, S.A., Del Coco, L., Migoni, D., Carrozzo, L., Mancinelli, G., Fanizzi, F.P., 2016. ${ }^{1}$ H NMR metabolomic profiling of the blue crab (Callinectes sapidus) from the Adriatic Sea (SE Italy): a comparison with warty crab (Eriphia verrucosa), and edible crab (Cancer pagurus). Food Chem. 196, 601-609.

Zotti, M., Del Coco, L., De Pascali, S.A., Migoni, D., Vizzini, S., Mancinelli, G., Fanizzi, F.P., 2016. Comparative analysis of the proximate and elemental composition of the blue crab Callinectes sapidus, the warty crab Eriphia verrucosa, and the edible crab Cancer pagurus. Heliyon 2, 1-15. 